\title{
Paul Verlaine
}




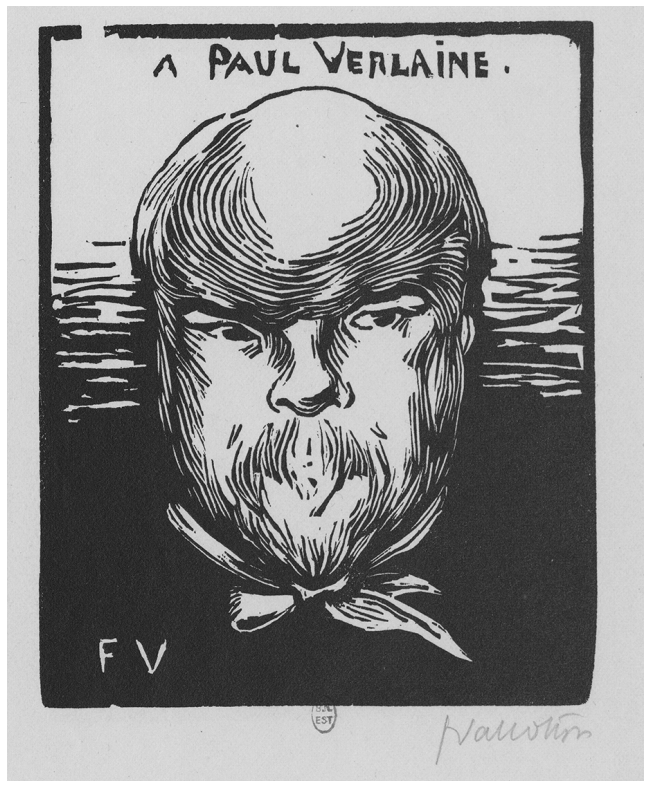




\section{Paul Verlaine}

\section{A Bilingual Selection of His Verse}

Translated by

Samuel N. Rosenberg
Edited by

Nicolas Valazza 
Frontispiece: Félix Vallotton, À Paul

Verlaine, I89I. Photo: Bibliothèque nationale de France.

Library of Congress Cataloging-in-

Publication Data

Names: Verlaine, Paul, 1844-I896, author.

| Rosenberg, Samuel N., translator. |

Valazza, Nicolas, editor.

Title: Paul Verlaine : a bilingual selection of his verse / translated by Samuel N. Rosenberg ; edited by Nicolas Valazza.

Description: University Park, Pennsylvania : The Pennsylvania State University Press, [2019] | Includes bibliographical references and index. | Poems in French with English translations on facing pages.

Summary: "An anthology of works by nineteenth-century French poet Paul Verlaine, presenting both the French texts and new translations and setting the poems in the context of Verlaine's troubled life and his literary development"-Provided by publisher.

Identifiers: LCCN 2019028833 | ISBN 9780271084930 (cloth)

Subjects: LCSH: Verlaine, Paul, I844-I896Translations into English. | LCGFT: Poetry.

Classification: LCC PQ2463.A2 2019 | DDC $84 \mathrm{I} / .8-\mathrm{dc} 23$

LC record available at https://lccn.loc .gov/2019028833
Many variations appear in the published French texts of Verlaine's poetry. The French versions included in this volume have been selected and verified by Nicolas Valazza.

Translations and Translator's Note copyright 2019 by Samuel N. Rosenberg. Some translations were previously published in Metamorphoses. The Translator's Note began as a presentation to a Translation Seminar at the Indiana University Lilly Library.

Annotations and other editorial apparatus copyright 2019 by Nicolas Valazza.

\section{Copyright (C) 2019}

The Pennsylvania State University

All rights reserved

Printed in the United States of America

Published by The Pennsylvania

State University Press,

University Park, PA I6802-I003

The Pennsylvania State University Press is a member of the Association of University Presses.

It is the policy of The Pennsylvania State University Press to use acid-free paper. Publications on uncoated stock satisfy the minimum requirements of American National Standard for Information Sciences-Permanence of Paper for Printed Library Material, ANSI Z39.48-I992. 